G. Le Bon, G. Mead, and G. Tarde addressed this problem. According to the latter, identity is not only a social phenomenon but also a process. In this case, it is not so much about the concept of «identity» as it is about «identification», that is, the process in which a person interacts with society and as a result of it (interaction) assumes social roles in relation to one or another collective action of a social group. Such an instruction is of particular importance to our research, since it points to possible ways of reformatting identical constructions - the setting of qualitatively other projective tasks in the field of social-humanitarian policy by civic institutions. In addressing the definition of «with what?», actually, identity emerges under such conditions and in what terms to speak about it, the work of the well-known Lithuanian intellectual L. Donskins «Confused Identity and the Modern World» is published. A cross-section of the national-cultural definition of identity is offered by a collective monograph of Ukrainian philosophers, "National Identity and Civil Society», which has become perhaps the main reference point in understanding the particularities of national identity as a humanitarian security constant for this study. Conclusions. So, by healing oneself in the way of overcoming embarrassment and asserting own identity, a person becomes ready to be responsible for every act of his life-long progress as ultimately determining for his or her collective being, that is, for the whole people. In other words, being prepared to become a model is a way of forming belonging to the world of collective values and tolerant policy of recognition. Besides, it is also the imperative to preserve identity health. This, therefore, is a challenge for ourselves - the formation of the new European identity in Ukraine through the restoration of historical memory as the affirmation of the cultural narrative for the present and the future. This is, in fact, the first step in creating «own philosophy» - the culture of ideas and nurturing of self-esteem, not only as a theoretical principle, but also as a daily life-practical duty: world-view priorities, ways of thinking, results of value reformatting as a process of continuous improvement.

Therefore, based on such guidelines and the real Ukrainian situation, it can be argued that humanitarian security in the aspect of forming collective identity is a certain balance of national-spiritual values with socio-political ones, this world-view health is embodied by intellectual taste, it is the awareness of the multiplicity of spiritual paths as political unity. This is the way which the modern Ukrainian is moving towards in the civilized world. It is, therefore, a question of democratic principles as a result of the self-development of society from the social science standpoint, from a philosophical point of view - the possibility of the essential progress of the contemporary as the development of the capacity of own collective identity. Identity, therefore, allows one to have history or fully produce a historical narrative, claiming own exclusive rights as a narrator, who connects the past with the future, thus conveying and reinforcing the tradition. Thus, identity serves as a passport to the self-legitimization of a cultural narrative, for which there is no concept of fate in the modern world, it must enable itself and secure itself through its self-awareness.

Key Words: identity, authenticity, values, humanitarian security, embarrassment and assertion of identity, cultural narrative, identity health.

UDC1:316.327

J. V. Kharchenko

\title{
THE PARADOX OF INTERACTION: "UNIQUE" AS COMPREHENSIVE (TRANSCENDENTAL APPROACH)
}

\author{
Volodymyr Vynnychenko Central Ukrainian State Pedagogical University;
} kharchenkojv@gmail.com

\begin{abstract}
The paradox of the interaction of "unique", "universal" and "comprehensive" through the use of classical postulates of fundamental as well as philosophical and theological knowledge was examined in accordance with the aim of the study. The ideal interaction models were conceptualized, following the key task. It was confirmed a possibility of distinguishing the basic provisions in fundamental sciences: recognizing the reality of the existence of the world, patterns of its structure and the idea that the world can be cognizable by man. Within the key postulate in philosophy of "man - society - universe" interaction the categories of "man", "society", and "universe" were considered as ideal holistic constructions-singularities. Theological postulates were presented in the form of sacred texts reflected in the Revelation texts about the Comprehensive Logos; in the fundamental doctrine of the All-Powerful, Wise and All-Loving God, of His true essence and good deeds. The transcendental method was used to introduce a priori transcendental concepts - "unique", "comprehensive", "universal" which are a prerequisite for resolving the unique and universal interconditionality paradox, as well as their self-transcendence. In conclusion it was underlined that the points of view of a man as unique and divine as comprehensive and universal coincide precisely in the process of constructing the being of the social reality. That is, what a person does and creates is a predestination of the Comprehensive Logos.
\end{abstract}

Keywords: universal, comprehensive, unique, interaction.

\section{Introduction}

Modern fundamental research represents the tendency to generalize all existing theories in order to present a common concept of being, to construct a new holistic image of our universe, which probably exists along with many other universes. Here the main question arises: whether our universe is unique, or it is just one version of its multiple repetitions?

We can say that every science (quantum physics, astronomy, biology, genetics, medicine, cybernetics) forms its own new picture of the world, embracing all new ideas about existence. Many of these "bricks of the world" do not always add up to a solid wellcoordinated design. The combination of these paintings may also project new, previously unknown laws of nature. That is, the interaction of many pictures of the world gives rise to the image of a new reality. The mind, at the same time, always strives for a comprehensive understanding of things, for the end result, explaining the purpose and meaning of life. After all, for each individual his own life is unique and valuable. This reveals the paradox of the interaction between being and man.

In his study, V. Yevsyukov shows that the picture of the world depends directly on the nature of the human society that created it. In the early stages of development, consciousness identifies concepts such as "society," "nature," "universe." Here there is one of the archaic concepts of the universe in the image of an animal. The next step is to humanize the universe. Constantly overcoming the rigid dependence on nature, man more and more towers over it. Accordingly, his view of the cosmos, which is now presented to him in the guise of man, is changing (Евсюков, 1990: 121). 
We consider these statements to be fair if we consider the formation of nature and society through the eyes of man in historical retrospect, that is, we literally "see" how our own ideas about existence have changed. However, if we consider being in itself, it is still a "thing in itself" for us. We cannot explore it using only empirical methods, and transcendental approaches are also required today.

In the true philosophical sense of the word, society is created not only for the purpose of human survival and the production of more and more benefits, but also in order to create comfortable conditions for the truth-aware mind, for the exaltation of the spiritual personality, for the collective humanity aspiring to spirituality and creativity. In such a system of values, every human soul is unique and the collective Spirit is universal.

Modern science is aimed at the implementation of powerful projects in the near future, in particular, it will be about human cloning, the creation of artificial intelligence as an autonomous mind, the search for intelligent life in space, colonization of other planets and many other things. This, on the one hand, will help to solve complex practical problems, and, on the other hand, generates moral and ethical problems: it turns out that everything is not unique, if you look through the eyes of the narrow person. And the most important thing is that the future person will be repeated, he is physically immortal and not spiritual. There is no mystery; there is no miracle of the creation of the world. In such conditions, nothing should surprise a person, his aspirations and dreams are considered in a purely utilitarian sense of the word.

The most difficult dilemma is the attitude of the human phenomenon as a unique being to the universal existence, as well as the paradox of interaction of the universal and unique, comprehensive mind and universal mind.

This paradox is explained by the fact that man and the world as unique phenomena exist in reality and have to do with a certain universal whole, but the fact of their existence has no logical explanation. However, there are paradoxes that are explained only through philosophy, and this is its exceptional possibilities.

\section{The aim and the tasks}

From the above, the task of this study is to examine the paradox of the interaction of "unique", "universal" and "comprehensive" through the use of classical postulates of fundamental as well as philosophical and theological knowledge. The key task is to conceptualize the ideal interaction models.

\section{Research methods}

In basic sciences (logic, mathematics, natural sciences) there are some unconditional starting positions, axioms, which are used to build the system of knowledge as a whole. It is possible to distinguish the basic provisions: firstly, it is necessary to recognize the reality of the existence of the world, secondly, there are patterns of its structure and, thirdly, the world can be cognizable by man.

There is an approach in philosophy that allows the following: because of theoretical or practical necessity, a position, even without being proven, is accepted as true. At the same time, there are many theories that cannot be verified empirically. Also the key postulate is the thesis about the interaction of the "human-societyuniverse" and the essence of this interaction. The categories of "man", "society" and "universe" are considered as ideal holistic constructions-singularities.

There are "dogmas" in religion, that is, positions that cannot be proven. Theological postulates are presented: firstly, in the form of sacred texts reflected in the Revelation texts on the fishery of the Comprehensive Logos; secondly, in the fundamental doctrine of the AllPowerful, The Wise and the All-Loving God, of his true essence and good deeds; thirdly, in the proof of the truthfulness of the creed, in the system of religious cults, norms and rules of spiritual life.

Therefore, the description of ideal interaction patterns is possible if ontological and theological approaches are used.

The transcendental method is used in all sciences. It provides the introduction of a priori transcendental concepts - "unique", "comprehensive", "universal" which are a prerequisite for resolving the paradox of the interconditionality of the unique and the universal, as well as their self-transcendence. In theology, it forms a gnoseological proof of God's existence.

The transcendental method generally demonstrates the normative part of repetitive unique phenomena and captures the complex nature of the interactions of these phenomena at the communication process level (Wood, 2003: 15). It projects a set of individual mental and behavioral intentions of the subject and extrapolates them to the comprehensive.

\section{Research results}

The unique is often identified with the phenomenon.

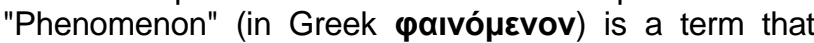
generally means a phenomenon given in sensual contemplation. In natural science a phenomenon refers to an observable phenomenon or event. Also a phenomenon is an unusual phenomenon, a rare fact, something that is difficult to comprehend. In idealistic philosophy: an accessible to human cognition phenomenon, opposed to the unknowable essence of it - "the noman". It is also possible to speak of an exceptional person in some respect, an outstanding person or a phenomenon (Скворцов, 2009: 934). Therefore, on the one hand, the phenomenon is unique, and, on the other hand, it is accessible for perception and habitable for a person, and therefore trivial.

The concept of "unique" generates a synonymous series and is thought of as: rare, exceptional, extraordinary, informal, outstanding, remarkable, phenomenal; inimitable, unsurpassed, one-of-a-kind, one-infrequent (Толковый словарь Ушакова: 952). This diversity of values shows that the unique is immeasurable. It has no limits and it is infinite if one considers its essence in depth. For example, it is impossible to compare two people with their spiritual and intellectual microcosms. These microcosms are unique and therefore not copied. That is, unique in its inner diversity resembles the universal or rises to it.

"Comprehensive" and "universal" are understood as embracing and comprehending everything (Толковый словарь Ушакова: 401). But if the unique is exceptional, although we can observe it, then the 
universal is not observed and incomprehensible, and therefore sacred.

The majority of representatives of the millennial philosophical tradition speaks about the nature of divine origin and sacred existence. Modern philosophy also does not exclude the existence of sacred. The sacred comprehensive is concentrated in the philosophical and scientific concepts of the past in the image of universal God. K. Fischer argues that the development of church teaching focuses primarily on solving the following three problems: how to think the being of God, Christ and man? And are our ideas about the fact of redemption consistent among themselves in all three paragraphs? He believes that the first question is a theological problem, the second is a Christological one, and the third is an anthropological one (Фишер, 2003: 92). This thesis shows that the sacred universal cannot be comprehended without a unique human.

Comparing the positions of some representatives of the philosophy of science of the New Time, K. Fischer came to the conclusion that under Bacon the spirit cannot be explained by natural reasons, which, therefore, the knowledge of the spirit refers not to psychology, but to theology, which learns about supernatural causes through revelation. Bacon himself, according to the researcher, recognizes - and this is of the greatest importance for judgment of his philosophy - that philosophy cannot explain the spirit (Фишер, 2003: 387). The category of "spirit" refers us to the deep essence of the comprehensive mind and universal being.

K. Fischer also showed that Spinoza's order of things is certainly defined, and yet from eternity: this is the "predestination of God". Therefore, random events cannot be performed in natural things, and there can be no unconditioned, or free, will. There is no accidental phenomenon, for such a phenomenon would have no cause, which is impossible, or its cause would either exist by accident or act by accident; both recent cases are also impossible, the randomness of existence eliminates any need, including the need for the first cause, and the randomness of the action is tantamount to inaction, as there is no defining basis, without which nothing is being done (Фишер, 2005: 158). On this basis, it can be argued that the universal essence is predestination. Any thoughts or actions have a sacred purpose and are caused by the highest cause. The pantheistic currents do not impoverish the essence of the divine, do not reduce God to the things he created, but, on the contrary, enrich things and give them uniqueness, supreme value.

The things he created are also fully unknowable; man is not close to the essence of true being, so how can he know the essence of a universal God? The contemporary philosopher J.-P. Sartre emphasizes that being is becoming, it is on the other side of the formation. It is what it is; it means that by itself it cannot even be the being of what it is not: indeed, we see that it does not hide any denial. It is the exact opposite. It, therefore, does not know variability. It never considers itself to be anything other than other being. It cannot maintain any relationship with the other. It is boundless and exhausted by being. From this point of view it in principle eludes time. It is, and when it collapses, it cannot even be said that it is no longer there, or at least consciousness can recognize it as no longer being real, because it is in time. But being itself does not exist as a disadvantage where it was: the completeness of the positivity of being is again formed at the site of the collapse. It was, and now there are other things (Сартр, 2009: 59). He presented being as a kind of "pure being" that exists "for ourselves" beyond cognitive perception, and each manifestation of it "for us" is unique. Although the author does not directly point to the theological and Christological nature of being as a sacred comprehensive, he agrees with his timeless nature.

In his turn, K. Jung noted that the realization of self, logically following from the recognition of its supremacy, leads to a fundamental conflict, to a true suspension between two opposites (reminiscent of the crucified Christ, suspended between two robbers) and to a state of approximate integrity devoid of perfection. To strive for "teloss" (completeness) in the sense of perfection is not only permissible, but also simply an innate property of man, one of the most powerful roots of civilization (Юнг, 2009: 95). The researcher also confirms our idea of the interconditionation of the unique and the universal. The paradox of such interaction is presented in the image of Christ-Man as a diada consisting of incompatible opposites.

In K. Jung, the image of Christ is quite consistent with the situation: Christ is a perfect man who was crucified. It is hardly possible to think of a more accurate mapping of the purpose of ethical efforts. In any case, the transcendental idea of self, which serves as a working hypothesis in psychology, is not able to compete with this image, although it is a symbol, it is still devoid of the character of a historical event that serves as a revelation. Like the oriental ideas of Atman and Dao, correlated with it, the idea of self, at least in part, is a product of cognition, conscious and not on faith, and not on metaphysical speculation, but on that experienced fact that under certain conditions the unconscious spontaneously generates an archetypal symbol of integrity (Юнг, 2009: 95-96). But, on the other hand, it is possible that the presence of complex mental structures and the ability to metaphysical sense of the sacred things form the divine person. After all, it is bodily similar to other individuals, but emotionally, spiritually, intellectually, it is significantly different from them. Only such a person is able to feel the miracle of the phenomenon of Christ.

Such a thought prevails just in our national philosophical tradition. L. Karsavin emphasizes that the Deity is absolute, being the Unity and comprehending us as such. But in the fullness of our experience, It is absolute only on the condition that in some sense something different from Him exists, without limiting His absoluteness. And this "something" exists in order not to limit God and, being different from $\mathrm{Him}$, somehow to resist Him, it must not be self-existence or something, that is, in its identity it is perfect nothing, if it is even the slightest point of it, it is no longer different from God or God is limited by it (Карсавин, 2003: 32). The thinker justified the idea of absolute unity of the divine, which is completely different from even the most perfect and 
unique forms of life created by him, although it is directly related to each event and to everything. The human mind, on the other hand, is not even remotely able to measure and understand its comprehensiveness.

In this regard, E. Chudinov notes that when we say that the world has some geometry, we should be aware that by the world we understand a certain picture of the world. And since the picture of the world is based on some theory, the question of real geometry is solved not in an absolute sense, but only in relation to this theory (Чудинов, 1974: 156). This does not mean that all our theories are false, they only allow us to understand the essence of the time in which we live and the purpose of the material things we need for everyday life.

\section{Discussion}

Modern researchers pay attention to the transcendental nature of the inner world of moral personality. S. Kharchenko analyzed the philosophical texts of I. Kant, who formulated fundamental postulates about morality, about being of moral personality (Харченко, 2019: 83). Cultural-historical and comparative principles allowed the author to compare and reveal the distinctive features of past and modern moral and ethical systems. At the same time, it turned out that all moral and ethical systems have common features, they are universal in terms of perceiving a person as a unique spiritual human being.

E. Sidorkina in her works speaks about the relationship of individual and social in being of personality (Сідоркіна, 2019: 70). That is, in the very nature of man there is antinomy - a situation in which his contradictory entities (spiritual and bodily) or social facets (individual and public) have a logically equal justification and their truth or falsehood cannot be substantiated within any accepted moral and ethical paradigm. That is, these entities and facets are equally recognized, but there is a contradiction between them.

F. Grzhelinsky and M. Lagos emphasize the exceptional complexity of consciousness and its metaphysical bases as opposed to an immaterialistic approach to the analysis of perception in animals (Grzelinski, Lagosz, 2019: 8). Metaphysics sees consciousness as an immeasurably complex abstraction, a topological construct that is inaccessible to experience because it is the ideal beginning of the inner world. It is a spiritual phenomenon, not a material one; it exists as a microcosm outside of its mutual connections, outside of movement, change and development. This is the uniqueness and universality of consciousness.

\section{Conclusion}

It follows that there is a conflict between the unique and the trivial, the real and the fictional, the divine and the fussy. It is a conflict "for us". Therefore, we constantly change social reality, model fictional worlds, look for more and more comfortable variations for interaction and communication.

In our previous studies, we have analyzed the phenomenon of interaction in the topology of imaginary realities (Grzelinski, Lagosz, 2019: 30). We considered different models of such realities, reflecting random and non-random connections in the society, in the spiritual and virtual dimensions of the social being. It turned out that "imaginary reality" is a kind of "imaginarium", a set of assumptions of mind about the true image of the real world. It is formed by building many alternative ideal systems that set their own rules and laws. The current modern world we have built is unique in its own way. And every person in it is unique.

The universal also creates its own imaginarium. It's all that they've created; it's also the world in which we exist. This world is not only nature, but also society and humanity. But humanity is also creative; it is creating its own model of life. Therefore, the points of view of man as unique and divine as a comprehensive and universal coincide precisely in the process of constructing the being of the social. That is, what a person does and creates is a predestination of the Comprehensive Logos.

\section{Literature}

1. Евсюков В.В. Мифы о мироздании. Мироздание и человек / В. В. Евсюков. - М.: Политиздат, 1990. - С. 7-123.

2. Карсавин Л. П. Путь православия / Л. П. Карсавин; сост. и вступ. ст. П. О. Никонова. - М.: АСТ; Харьков: Фолио, 2003. - 557, [3] c.

3. Сартр Ж.-П. Бытие и ничто. Опыт феноменологической онтологии / Ж.-П. Сартр; [пер. с фр.]. - М.: АСТ, 2009. 925, [3] с.

4. Сідоркіна О. М. Людина індивідуальна та колективна у феномені робінзонади / О.М. Сідоркіна // Вісник Національного авіаційного університету. Серія: Філософрія. Культурологія: Збірник наукових праць. - Вип. 1 (29). - К.: HAУ, 2019. - С. 67-72.

5. Скворцов Л. И. Большой толковый словарь правильной русской речи: 8000 слов и выражений. - М.: Оникс; Мир и Образование, 2009. - 1104 с.

6. Толковый словарь Ушакова. Академик [Електронний pecypc]. Режим доступу: https:// dic.academic.ru/dic.nsf/ushakov/ 1068166. - Назва з екрану.

7. Фишер К. История новой фрилософии: Бенедикт Спиноза / К. Фишер [пер. с нем.]. - М.: АСТ; Транзиткнига, 2005. $-557,[3] \mathrm{c}$.

8. Фишер К. История новой фрилософии: введение в историю новой философии. Френсис Бэкон Веруламский / К. Фишер; [пер. с нем.]. - М.: АСТ, 2003. - 541, [3] с.

9. Чудинов Э. М. Теория относительности и философия / Э. М. Чудинов. - М.: Политиздат, 1974. - 304 с

10. Юнг К. Эон / К. Юнг; [пер. с нем. М. А. Собуцкого]. - М.: ACT, 2009. - 411, [5] c.

11. Grzelinski A., Lagosz M. The animal-machine concept in Descartes and Berkeley. The attempt at comparison. Вісник Національного авіаційного університету. 2019. Вип. 1 (29). С. 5-10. (Серія «Філософрія. Культурологія»).

12. Kharchenko S. P. «Categorical imperative» of I. Kant as a universal philosophical-legal paradigm. Вісник Національного авіаційного університету. 2019. Вип. 1 (29). - С. 82-86. (Серія «Філософія. Культурологія»).

13. Kharchenko Y. V. Link of accidental and non-accidental in multiverse of imaginary realities. Вісник Національного авіаційного університету. 2019. Вип. 1 (29). - С. 26-31. (Серія «Філософрія. Культурологія»).

14. Wood J. T. Interpersonal Communication: Everyday Encounters. Rel. Lib, 2003. - 349 p.

\section{References}

1. Evsiukov, V.V. (1990). Mify o mirozdanii [Myths about the Universe]. Mirozdanie i chelovek, Universe and man. Moscow: Politizdat [in Russian]

2. Karsavin, L.P. (2003). Put pravoslaviia [The path of Orthodoxy]. P.O. Nikonova (Ed.). Moscow: AST; Kharkov: Folio [in Russian].

3. Sartr, ZN.-P. (2009). Bytie i nichto [Being and nothing] Opyt fenomenologicheskoy ontologii, The experience of phenomenological ontology. (Trans). Moscow: AST [in Russian]. 
4. Sidorkina, O.M. (2019). Liudyna indyvidualna ta kolektyvna $\mathrm{u}$ fenomeni robinzonady [Man is individual and collective in the phenomenon of robinsonade]. Visnyk Natsionalnoho aviatsiinoho universytetu, Proceedings of the National Aviation University, 1(29), 67-72 [in Ukrainian].

5. Skvortsov, L.I. (2009). Bolshoy tolkovyy slovar pravilnoy russkoy rechi: 8000 slov i vyrazneniy [Large explanatory dictionary of correct Russian speech: 8000 words and phrases]. Moscow: Oniks; Mir i Obrazovanie [in Russian].

6. Tolkovyy slovar Ushakova [Explanatory Dictionary of Ushakov]. Sait "Akademik", Site "Academician". dic.academic.ru. Retrieved from https://dic.academic.ru/dic.nsf/ushakov/1068166 [in Russian].

7. Fisher, K. (2005). Istoriia novoy filosofii: Benedikt Spinoza [The Story of a New Philosophy: Benedict Spinoza]. (Trans). Moscow: AST; Tranzitkniga [in Russian].

8. Fisher, K. (2003). Istoriia novoy filosofii: vvedenie $v$ istoriiu novoy filosofii. Frensis Bekon Verulamskiy [The History of New Philosophy: An Introduction to the History of New Philosophy. Francis Bacon of Verulam]. (Trans). Moscow: AST [in Russian].
9. Chudinov, E.M. (1974). Teoriia otnositelnosti i filosofiia [Theory of Relativity and Philosophy]. Moscow: Politizdat [in Russian].

10. lung, K.G. (2009). Eon [Eon]. (M.A. Sobutskiy, Trans). Moscow: AST [in Russian]

11. Grzelinski, A., \& Lagosz, M. (2019). The animal-machine concept in Descartes and Berkeley. The attempt at comparison. Visnyk Natsionalnoho aviatsiinoho universytetu, Proceedings of the National Aviation University, 1(29), 5-10.

12. Kharchenko, S.P. (2019). "Categorical imperative" of I. Kant as a universal philosophical-legal paradigm. Visnyk Natsionalnoho aviatsiinoho universytetu, Proceedings of the National Aviation University, 1(29), 82-86.

13. Kharchenko, Y.V. (2019). Link of accidental and nonaccidental in multiverse of imaginary realities. VVisnyk Natsionalnoho aviatsiinoho universytetu, Proceedings of the National Aviation University, 1(29), 26-31.

14. Wood, J.T. (2003). Interpersonal Communication: Everyday Encounters. Rel. Lib.

\section{Ю. В. Харченко}

ПАРАДОКС ВЗАИМОДЕЙСТВИЯ: «УНИКАЛЬНОЕ» КАК ВСЕОБЪЕМЛЕМОЕ (ТРАНСЦЕНДЕНТАЛЬНЫЙ ПОДХОД)

В исследовании рассматривается парадокс взаимодействия «уникального» и «всеобъемлемого» посредством использования классических постулатов фундаментального, фрилософского и теологического знания. Осуществлена концептуализация идеальных моделей взаимодействия, что является целью и ключевой задачей в данной статье. Показано, что в фундаментальном знании выделяются основные положения: о необходимости признания реальности бытия мира, существования закономерности его устройства и познаваемости его человеком.

Ключевые слова: универсальный, всеохватывающий, уникальный, взаимодействие.

\section{Ю. В. Харченко}

ПАРАДОКС ВЗАЄМОДІЇ: «УНІКАЛЬНЕ» ЯК ВСЕОХОПЛЮЮЧЕ (ТРАНСЦЕНДЕНТАЛЬНИЙ ПІДХІД)

Вступ. Найбільш складною дилемою у філософії $є$ відношення феномена людини як унікальної істоти до всеохоплюючого буття. Цей парадокс пояснений тем, що і людина, і світ, як унікальні феномени, існують в реальності й тяжіють до деякого всеохоплюючого цілого, проте факт їхнього існування не має логічного пояснення. Метою даної роботи $є$ дослідження парадоксу взаємодії «унікального» та «всеохоплюючого» за допомогою класичних фундаментальних, а також філософськобогословських знань. Завданням роботи $€$ здійснення концептуалізації «унікального» та «всеохоплюючого» як ідеальних моделей взаємодії. Методологією дослідження виступає трансцендентний метод, який забезпечує введення апріорних трансцендентних категорій - «унікальне», «всеохоплююче», що стали передумовою для розв'язання парадоксу взаємообумовленості унікального і загального, а також їхньої самотрансценденції. Результати. Показано, що у фундаментальному знанні виділяються головні положення: про необхідність визнання реальності існування світу, існування регулярності його устрою та пізнання його людиною. У фрілософіії, ключовим постулатом є теза про взаємодію «людинисуспільства-Всесвіту» та суті цієї взаємодії. У той же час, «людина», «суспільство», «Всесвіт» вважаються ідеальними цілісними конструкціями-сингулярностями. Богословські постулати представлені у вигляді священних текстів, відображених в Одкровенні, де представлений Всеохоплюючий Логос, в фундаментальній доктрині про Всемогутнього, Всемудрого і Вселюбного Бога, про його істинну суть і хороші діяння. Обговорення. Уточнено, що свідомість $є$ складною метафізичною абстракцією, топологічною конструкцією, яка недоступна емпіричному пізнанню, оскільки вона $€$ ідеальним центром внутрішнього світу людини. Це духовне явище, а не матеріальне, воно існує як безмежний мікрокосм. В цьому й проявляється одночасна унікальність $\mathrm{i}$ всеохопність свідомості. Висновки. Це дало змогу зробити висновок, що всеохоплююче створює свій власний уяви-всесвіт, в якому людина існує. Цей світ - не лише природа, а й суспільство. Але людство також є творчим, як і всеохоплююче, адже створює власну модель життя. Таким чином, точка зору людини як унікального і Бога як всеохоплюючого збігаються саме в процесі побудови буття суспільного. Тобто те, що людина робить і створює є її призначенням з боку Всеохоплюючого. Ключові слова: універсальний, всеохоплюючий, унікальний, взаємодія. 